\title{
Internationalization of Higher Education, Challenges and Opportunities for the Next Decade
}

\author{
Hans de Wit and Ligia Deca
}

Internationalization has evolved in higher education over the past 30 to 40 years from a marginal aspect to a key aspect of the reform agenda. It also has evolved in different directions and, in that process, some previous values have got lost, and past priorities have been replaced by others. Economic rationales have become more dominant, but as the society is facing extreme challenges, summarized in the Sustainable Development Goals (SDGs) of the United Nations, internationalization needs to respond to these challenges and goals. Some of the papers in this section address the sustainability and quality of the current state of internationalization, others look ahead and analyse whether new initiatives such as the European Universities initiative (EUI) are an answer, or how internationalization can address the need for higher education of refugees. It is important to place the papers in perspective of the evolution of internationalization as a basis for the next decade.

\section{Internationalization in Perspective}

Universities have always had international dimensions in their research, teaching and service to society, but those dimensions were, in general, more ad hoc, fragmented and implicit, rather than explicit (de Wit and Merkx 2012).

Comprehensive strategies are a rather recent development of the past three decades. In the last decade of the previous century, the increasing globalization and regionalization of economies and societies, combined with the requirements of the knowledge economy and the end of the Cold War, created a context for a

H. de Wit $(\bowtie)$

Center for International Higher Education, Boston College, Chestnut Hill, United States

e-mail: dewitj@bc.edu

L. Deca

New Europe College, Bucharest, Romania

e-mail: deca.ligia@gmail.com 
more strategic approach to internationalization in higher education (Knight and de Wit 1995). This became manifest first and foremost in Europe (the EU programs and the Bologna Process), but gradually also elsewhere. The European Commission, international organizations such as OECD, UNESCO and World Bank, national governments, as well as higher education organizations such as the International Association of Universities (IAU) and the European Universities Association (EUA) placed internationalization at the top of the reform agenda. Internationalization became a key change agent in higher education, in the developed world, but also in transitional democracies and developing societies, who also used international trends to justify unpopular reforms (de Wit et al. 2015). Some of these societies, particularly in regions such as Central and Eastern Europe, can be seen as 'laboratories of reform' in terms of the effect of internationalization of higher education on the overall evolution of the higher education system (Dakowska and Harmsen 2015; Deca 2016).

Mobility of students, scholars and programs; reputation and branding (manifested by global and regional rankings), and a shift in paradigm from cooperation to competition were the main manifestations of the agenda of internationalization in higher education over the past 30 years. International education became an industry, a source of revenue and a means for enhanced reputation and soft power.

Quantitative data about the number of international degree- seeking students, of international talents and scholars, of students going for credits abroad, of agreements and memoranda of understanding, as well as of co-authored international publications in high impact academic journals, were not only the key manifestations of this perception of internationalization, but also did and still do drive its agenda and actions.

All these aspects of internationalization resulted in an increasing dominance of English in research but also teaching, created the emergence of a whole new industry around internationalization, forced national governments to stimulate institutions of higher education going international, and did enter new buzz words such as crossborder delivery and soft power in the higher education arena.

In the period 2010-2020, we see not only the number of international students double to five million, but we also notice an increase in franchise operations, articulation programs, branch campuses and online delivery of higher education. There is fierce competition for talented international students and scholars, and selective immigration policies have shifted from low-skill to high skill immigration.

National excellence programs have increased differentiation in higher education, with more attention being given to a small number of international world-class universities and national or even regional flagship institutions which compete for talents, for positions in the global rankings, for access to high impact journals, and for funding, at the cost of other institutions.

But internationalization has also become more globalized, and regional, national and institutional initiatives are developed in the emerging and developing world: 
In the current global-knowledge society, the concept of internationalization of higher education has itself become globalized, demanding further consideration of its impact on policy and practice as more countries and types of institution around the world engage in the process. Internationalization should no longer be considered in terms of a westernized, largely Anglo-Saxon, and predominantly English-speaking paradigm (Jones and de Wit 2014, p. 28, see also de Wit et al. 2017).

Internationalization became defined by the generally accepted definition of Jane Knight (2008):

The process of integrating an international, intercultural or global dimension into the purpose, functions and delivery of post-secondary education

describing clearly the process in a general and value-neutral way.

Some of the main trends in internationalization in the past 30 years have been:

- More focused on internationalization abroad than on internationalization at home;

- More ad hoc, fragmented and marginal than strategic, comprehensive and central in policies;

- More in the interest of a small, elite subset of students and faculty than focused on global and intercultural outcomes for all, so little to no inclusiveness and equity;

- Directed by a constantly shifting range of political, economic, social/cultural, and educational rationales, with increasing focus on economic motivations;

- Increasingly driven by national, regional, and global rankings;

- Little alignment between the international dimensions of the three core functions of higher education: education, research, and service to society;

- Primarily a strategic choice and focus of institutions of higher education, but increasingly also a priority of national governments (soft power, reputation and/or revenue- driven) and regions (European Union, Bologna signature countries, ASEAN);

- Following already well-established models - mainly promoted by "big players" with enough economic clout and tradition in higher education promotion: the UK, USA, France, Germany etc.

Traditional values that did drive international activities in higher education in the past, such as exchange and cooperation, peace and mutual understanding, human capital development and solidarity, although still present in the vocabulary of international education, have moved in that process to the sideline in a strive for competition, revenue and reputation/branding.

\section{Rethinking and Redefining Internationalization}

Around the change of the century, we observed already a first response to these developments. The movement for Internationalization at Home within the European Union started in 1999 in Malmö, Sweden, asking more attention to the $95 \%$ of 
non-mobile students, not participating in the successful flagship program of the EU, ERASMUS.

In the UK and Australia, a similar movement asked for attention for internationalization of the curriculum and teaching and learning in response to the increased focus on recruiting income- generating international students.

And in the US, attention emerged around internationalizing the campus and developing more comprehensive approaches to internationalization as an alternative for the marginal and fragmented focus on undergraduate study abroad on the one hand and international student recruitment on the other.

These reactions were and are important manifestations of concern about the competitive, elitist and market-oriented direction of internationalization, and call for more attention to the qualitative dimensions of internationalization, such as citizenship development, employability and improvement of quality of research, education and service to society, from output to outcome and impact.

In the past decade, one can observe an even stronger reaction to these trends. While mobility is still the most dominant factor in internationalization policies worldwide, there is increasing attention being paid to internationalization of the curriculum at home and from physical mobility to virtual mobility and exchange, collaborative online international learning.

There is also a stronger call for the comprehensiveness of internationalization, addressing all aspects of education in an integrated way. Although economic rationales and rankings still drive the agenda of internationalization, there is more emphasis now being placed on other motivations for internationalization, political, academic, social, cultural.

For example, attention is being paid to integrating international dimensions into tertiary education quality assurance mechanisms, institutional policies related to student learning outcomes, and the work of national and discipline-specific accreditation agencies (de Wit 2019).

A wide range of academic scholars and international education practitioners push with their publications and presentations the agenda for change and rethinking internationalization.

A study for the European Parliament on the state of internationalization in higher education gave this push an extra dimension. Not only provided the study a comprehensive overview of the literature and the practice of internationalization in higher education around the world, but also-based on a global Delphi Exercise-it promoted a new agenda for internationalization for the future, by extending the definition of Jane knight of 2004, defining that direction as follows:

\footnotetext{
The intentional process of integrating an international, intercultural or global dimension into the purpose, functions and delivery of post-secondary education, in order to enhance the quality of education and research for all students and staff and to make a meaningful contribution to society (de Wit et al. 2015, European Parliament Study)
}

This definition gives a normative direction to the internationalization of higher education by emphasizing that such a policy process does not and should not go on by itself, but needs clear intentions, that internationalization is not a goal in itself, but 
needs to be directed towards quality improvement, that it should not be of interest only to a small elite of mobile students and scholars, but directed to all members of academic communities, and that it should make a clear contribution to society.

\section{Challenges and Opportunities for the Next Decade}

Over the past five years and in light of the new UN agenda for the achievement of the Sustainable Development Goals, this new approach has received positive attention, and at the start of a new decade, it is important to see if this shift back to a more ethical and quality approach with respect to internationalization is indeed taking place and what new dimensions one can observe in that shift.

Internationalization of higher education is entering a new phase. A shift from internationalization abroad with a strong focus on a small elite of mobile students, faculty, administrators and programs towards internationalization at home for all students, faculty and administrators is even more urgent than ever.

Making internationalization more carbon-neutral (de Wit and Altbach 2020), addressing more the importance of the contribution of internationalization to society (Brandenburg et al. 2019) and linking the global to the local are imperative.

Reducing short-term mobility of less than 8 weeks, making mobility in programs like Erasmus+ obligatory carbon-neutral, diminishing the need for administrative travel, supporting more actively virtual exchange and collaborative online international learning, addressing the needs of immigrant and refugee populations, are some of the key tasks of internationalization in the next decade. The benefits of emerging in a different culture, such as developing intercultural competences and skills, are without discussion, but a policy focused on making these more carbon-neutral-longer stays, using more sustainable forms of transport—would be welcome.

Also, it is high time to talk about what should be the role of national authorities and how much national strategy building is beneficial to the efforts of higher education institutions in terms of internationalization. Even the notion of national strategy for internationalization is something that needs more reflection, especially in light of the need to support institutional autonomy and public responsibility of higher education institutions. Finally, the impact of high profile new projects needs to be assessed, such as the European Universities Initiative, since they might redefine internationalization as we now know it, as well as national legal frameworks if original intentions materialize.

Several papers in the internationalization section address some of these new key issues: institutional, national and regional initiatives such as the European Universities Initiative; and how to deal with forced internationalization of refugees in higher education. 


\section{National Policies}

National governments increasingly see internationalization of higher education as an important factor in national economic development, trade and reputation. In light of enhanced student and staff mobility, the increased presence of branch campuses and international providers, and booming competition for international talent, tertiary education institutions and national governments are mobilizing to both leverage and steer internationalization. National tertiary education internationalization strategies and plans represent the most tangible and direct attempts by governments to play an active and decisive role in relation internationalization, but there are substantive differences in their approaches, rationales and priorities.

A worldwide census of explicit national policies carried out by Crăciun (2018) reveals that only $11 \%$ of countries have an official strategy for internationalization, most having been adopted in the last decade. Such strategies have been developed predominantly by developed countries-3 in 4 come from members of the Organisation for Economic Co-operation and Development (OECD). European countries have taken the lead in promoting strategic thinking about internationalization at the national level -2 in 3 come from this world region, and programs such as Erasmus+ and Horizon 2020 have led to further regional harmonization of higher education systems (British Council 2017).

This is not to say that other countries have not taken measures to promote internationalization. In fact, to support internationalization processes, many countries have taken both direct measures (e.g. re-evaluating their visa policies to give preferential treatment to international students and scholars, establishing bi-lateral or multilateral agreements through memoranda of understanding, and promoting transnational education through free-trade deals) and indirect measures (e.g. supporting internationalization in political discourses and giving universities autonomy to pursue internationalization activities).

The main focus in internationalization strategies and plans is still at the institutional level. Indeed, institutions operate in many cases without a national plan in place. Where national plans do exist, institutions may operate in conflict or in alignment with the national agenda. A national policy can serve as a catalyst or a drag on internationalization processes, but is mostly seen as a highly positive element for the advancement of internationalization. They align internationalization with other key national priorities, such as economic growth and national security. They incentivize institutions and individuals to assist in meeting national strategic goals through internationalization. In short, national internationalization strategies and plans offer not only a good overview of the manifestations of internationalization, but can also shape key action, provided they are reasonably well-resourced and monitored.

However, it would be a misconception to assume that national plans and policies have common rationales and approaches to internationalization. Differences exist between and among high-income, low-income, and middle-income countries with respect to their policies and practices, despite the obvious temptation to focus on flagship dimensions of internationalization, such as mobility, rankings or publishing 
performance. Also, there are differences in explicit and implicit policies and practices, with some countries having well- documented plans, and others having no plans but well-defined activities. More research could perhaps go into what drives similar approaches in terms of higher education internationalization based on national historical and social context, as well as cultural heritage.

Three papers analys e national policies for internationalization. Ligia Deca compares the national policies of Romania and Portugal, as two countries that went through transition from dictatorships to democracy in a similar regional context. Robert Santa and Cezar Mihai Haj look at demographic policies in the internationalization of Romanian higher education. And Pusa Nastase analyses drivers for internationalization in Georgian higher education.

\section{European Universities Initiative}

In 2018, a major European Union initiative was the call for proposals and consequent approval of pilot networks for the European Universities Initiative (EUI). This scheme followed French president Macron's political impetus to create a new type of university collaboration scheme that will drive educational innovation and quest for excellence across Europe. Although it is still too early to come to conclusions on this initiative, for which the second call just opened, Andrew Gunn in his contribution places the initiative in a context of alliance formation and a means for furthering the internationalization of higher education. The challenges with the EUI are several, in particular: is it possible to get universities comprehensively work together, and will the networks be more political and geographic compromises or realistic institutional alliances? One has to see if this attempt will be more successful than previous initiatives to create truly European universities (Orr et al. 2019).

\section{Increased Erasmus+ Support}

Both the European Commission and European Parliament are supportive of increasing the funding for and mobility of students and teachers in the flagship Erasmus+ program. In itself, this is positive, but it requires more analysis of the conditions under which this program can be successful and what are its measurable benefits. Several papers address these questions. Adriana Perez and Jerome Reichmann look at the current context and status of European career services, trying to identify how the formation of international career service consortia could contribute to improving the benefits of internationalization. Daniela Crăciun, Kata Orosz and Viorel Proteasa try to answer the question: does international student mobility have a positive impact on graduate employability? Cristina Ramona Fit takes a different approach, giving an example of how Romanian universities promote their educational offers and whether these marketing efforts are in line with their wider institutional strategies. And Peter 
Holicza provides an insight in a complementary scheme, CEEPUS, focused on collaboration and exchange in Central and Eastern Europe, with a focus on how this existing program could and should evolve in the future.

\section{Forced Internationalization}

As Ergin and de Wit state in their paper, much attention has been given over the past recent years to the challenges of developed countries in receiving refugees from developing countries, as in the Syrian case where the refugees who have been able to enter countries like Germany were closely followed by media reports. But the large majority of refugees are not only coming from the developing world, but are also hosted in the developing world. The unceasing war in Syria and long stay of the "unexpected" Syrian guests "forced" the Turkish government to make academic and financial reforms to enhance their access to Turkish higher education, which is introduced as 'forced internationalization of higher education' in the literature (Ergin et al. 2019). Attention to access, support and retention of refugees within the European Union countries is important, but as they state, based on the case of Syrian refugees in Turkey, attention to these issues in the developing world is even more important.

In summary, internationalization in higher education is an evolving process and changes in response to changes in the local, national, regional and global environment. The Sustainable Development Goals of the United Nations and Climate Change initiatives by the European Union will most likely be the inspiration for a rethinking of internationalization from a competitive market orientation to a social enterprise. At the start of the 2020 decade, it is important to look at the challenges and opportunities for the future and how the Bologna Process can influence that process. And this reflection will surely add to a wider conversation that keeps coming back in the context of the European Higher Education Area-what can European cooperation add to forward- looking, high quality, equitable higher education systems at national level?

\section{References}

Brandenburg, U., de Wit, H., Jones, E. \& Leask, B. (2019). Internationalisationin Higher Education for Society. University World News, 20 April 2019, issue 548.

British Council (2017). The Shape of Global Higher Education: International Mobility of Students, Research and Education Provision. Retrieved from www.britishcouncil.org/education/ihe

Crăciun, D. (2018). Navigating national internationalisation policies: Moving internationalisation from the periphery to centre stage. Forum. Amsterdam: European Association for International Education. 
Dakowska, D., \& Harmsen, R. (2015). Laboratories of reform? The Europeanization and internationalization of higher education in central and Eastern Europe. European Journal of Higher Education, 5(1), 4-17

Deca, L. (2016). Understanding the internationalization of higher education as a policy process: the case of Romania, PhD thesis, University of Luxembourg: http://orbilu.uni.lu/handle/10993/ 31206

de Wit, H. (2019). Internationalization in Higher Education: A critical review. Pp. 9-17. Special Issue: Internationalization of higher Education. SFU Educational Review, 12 (3).

de Wit, H., \& Altbach, Ph. G. (2020). Time to cut international education's carbon footprint. University World News, 11 January 2020, issue 580.

de Wit, H., \& Merkx, G. (2012). The history of internationalization of higher education. In Deardorff, de Wit, Heyl \& Adams, (Eds.), The SAGE Handbook on International Higher Education. Pp. 43-60. Sage Publications, Thousand Oaks, USA.

de Wit, H., Hunter, F., Egron-Polak, E., \& Howard, L. (Eds). 2015. Internationalisation of Higher Education. A study for the European Parliament, Brussels.

de Wit, H., Gacel-Avila, J., Jones, E., \& Jooste, N. (Eds.). 2017. The Globalization of Internationalization: Emerging Voices and Perspectives. Internationalization in Higher Education Series, Routledge.

Ergin, H., de Wit, H., \& Leask, B. (2019). Forced Internationalization: An Emerging Phenomenon. International Higher Education, no. 97, Spring 2019, pp. 9-10.

Jones, E., \& de Wit, H. (2014). Globalized Internationalization: Implications for Policy and Practice. In IIEnetworker, Spring 2014, pp. 28-29. IIE, New York

Knight, J. (2008). Higher education in turmoil: The changing world of internationalization. Rotterdam, The Netherlands: Sense Publishers.

Knight, J., \& de Wit, H. 1995. Strategies for internationalisation of higher education: historical and conceptual perspectives. In de Wit, H. (Editor). 1995. Strategies for Internationalisation of Higher Education, A Comparative Study of Australia, Canada, Europe and the United States of America. EAIE (in cooperation with IMHE/OECD and AIEA), Amsterdam.

Orr, E., Unangst, L., \& de Wit, H. (2019). The long, problematic road towards a European University. University World News, 7 April 2019, issue 546

Open Access This chapter is licensed under the terms of the Creative Commons Attribution 4.0 International License (http://creativecommons.org/licenses/by/4.0/), which permits use, sharing, adaptation, distribution and reproduction in any medium or format, as long as you give appropriate credit to the original author(s) and the source, provide a link to the Creative Commons license and indicate if changes were made.

The images or other third party material in this chapter are included in the chapter's Creative Commons license, unless indicated otherwise in a credit line to the material. If material is not included in the chapter's Creative Commons license and your intended use is not permitted by statutory regulation or exceeds the permitted use, you will need to obtain permission directly from the copyright holder.

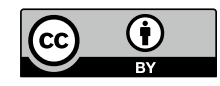

